\title{
Record and establishment of the non-native Loricariid catfish genus Pterygoplichthys (Siluriformes: Loricariidae) in the Coastal Plain of San Blas, Nayarit, Southeast Gulf of California, Mexico
}

\author{
José R. Tapia-Varela1, Deivis S. Palacios-Salgado ${ }^{2}$, Jesús T. Ponce-Palafox ${ }^{1,2, *}$, Carlos A. \\ Romero-Bañuelos ${ }^{1}$, José T. Nieto-Navarro ${ }^{2}$, Pedro Aguiar-García ${ }^{3}$ and Armando T. Wakida- \\ Kusunoki ${ }^{4}$ \\ ${ }^{1}$ Secretaría de Investigación y Posgrado, Universidad Autónoma de Nayarit, Tepic, Nayarit, México 63000. \\ 2 Escuela Nacional de Ingeniería Pesquera, Universidad Autónoma de Nayarit, Bahía de Matanchén, San Blas, \\ Nayarit, México. \\ ${ }^{3}$ Unidad Académica de Medicina. Universidad Autónoma de Nayarit. \\ ${ }^{4}$ Instituto Nacional de Pesca. Centro Regional de Investigación Pesquera, Yucatan, Mexico 97320. \\ * Corresponding author: jesus.ponce@usa.net
}

Received: 19/08/19

Accepted: $28 / 05 / 20$

\begin{abstract}
Record and establishment of the non-native Loricariid catfish genus Pterygoplichthys (Siluriformes: Loricariidae) in the Coastal Plain of San Blas, Nayarit, Southeast Gulf of California, Mexico

The establishment of non-native Loricariid catfish (Siluriformes: Loricariidae) of the genus Pterygoplichthys, in the Coastal Plain of San Blas, Nayarit, Southeast Gulf of California was reported. According to the morphological taxonomy and abdominal patterns, the specimens are closely related to the hybrid forms of $P$. pardalis $\mathrm{x} P$. disjunctivus. In addition, the evidence of its establishment in the study area is presented. The individuals were captured along the Mololoa River micro-basin, on the left bank of the lower Santiago river basin, in front of Matanchen Bay in addition to one in front of the sea beach at the mouth of the Santiago River. The mean length and weight of the fish caught from 2013 to 2016 were $25.2 \pm 2.2 \mathrm{~cm}$ and $123.2 \pm 27.9 \mathrm{~g}$. In the study area, uncontrolled propagation of this genus can jeopardize the diversity of fauna on the left bank of the Santiago river and the National Marsh ecosystem in the coastal plain of Nayarit, Mexico.
\end{abstract}

Key words: Pterygoplichthys, armored catfish, invasive species, Nayarit, México

\section{RESUMEN}

Reporte y establecimiento del bagre no-nativo Loricárido, género Pterygoplichthys (Siluriformes: Loricariidae), en la planicie costera de San Blas, Nayarit, Sureste del Golfo de California, México

Se reporta el establecimiento del bagre no-nativo Loricárido del género Pterygoplichthys (Siluriformes: Loricariidae) en la planicie costera de San Blas, Nayarit, Sureste del Golfo de California, México. La taxonomía morfológica y los patrones abdominales revelaron que los especimenes están estrechamente relacionados con formas hibridas de P. pardalis $x$ P. disjunctivus. Además, se presenta la evidencia de su establecimiento en el área de estudio. Los individuos fueron capturados a lo largo de una red de arroyos, canales, rios y lagunas interconectados y constituidos por la microcuenca del río Mololoa, margen izquierda de la cuenca baja del río Santiago, frente a la bahía de Matanchen y desembocadura del río Santiago. La longitudy el peso promedio de los peces capturados entre 2013 y 2016 fueron de $25.2 \pm 2.2 \mathrm{~cm}$ y $123.2 \pm 27.9 \mathrm{~g}$. Sin embargo, la propagación incontrolada de este género en el área de estudio puede ser una amenaza para la diversidad de la fauna de la cuenca baja del río Grande de Santiago y el ecosistema Marismas Nacionales en la llanura costera de Nayarit, México.

Palabras clave: Pterygoplichthys, bagre armado, especies invasoras, Nayarit, México 


\section{INTRODUCTION}

The utilization of fish for aquarium purposes has contributed significantly to the spread of organisms with invasive potential (Capps \& Flecker, 2013). The loricariids (Pterygoplichthys spp.), known as plecos, sailfin catfish or armored catfish, are native to South America, Costa Rica, Panama, and the Amazon Basin (Orfinger \& Goodding, 2018). Their territorial expansion worldwide began in the middle of the twentieth century (Ayala-Pérez et al., 2014). It is noteworthy that Loricariid catfish have established themselves as invasive species in various regions of the world, including Thailand (Chaichana \& Jongphadungkiet, 2012), Singapore, the Philippines, Indonesia, Malaysia, Vietnam, (Barba et al., 2014), Africa (Hoover et al., 2014), EE. UU (Hawaii), México, Japan, India, and Israel (Bijukumar et al., 2015; Muralidharan et al., 2015;
Wakida-Kusunoki et al., 2016). In Mexico, the two species that are particularly recognized are: Pterygoplichthys pardalis and $P$. disjunctivus (Mendoza et al., 2009; Wakida-Kusunoki et al., 2016). However, genetic evidence suggests that $P$. disjunctives represents a synonym for $P$. pardalis (Jumawan et al., 2011; Wu et al., 2011; Yu \& Quilang, 2014).

The territorial species of Pterygoplichthys have a high reproduction rate and parental care. Additionally, they are nocturnal and highly resistant to desiccation. These species can withstand varying conditions of water quality. Their hardened external morphology and spines allow them to evade predators, which, in turn, makes it possible for them to colonize new habitats. Pterygoplichthys has been classified as a genus with high invasive potential (Gibbs et al., 2008, Simonović et al., 2010, Capps \& Flecker, 2013, Zworykin \& Budaev, 2013, Bijukumar et al., 2015). Popula-

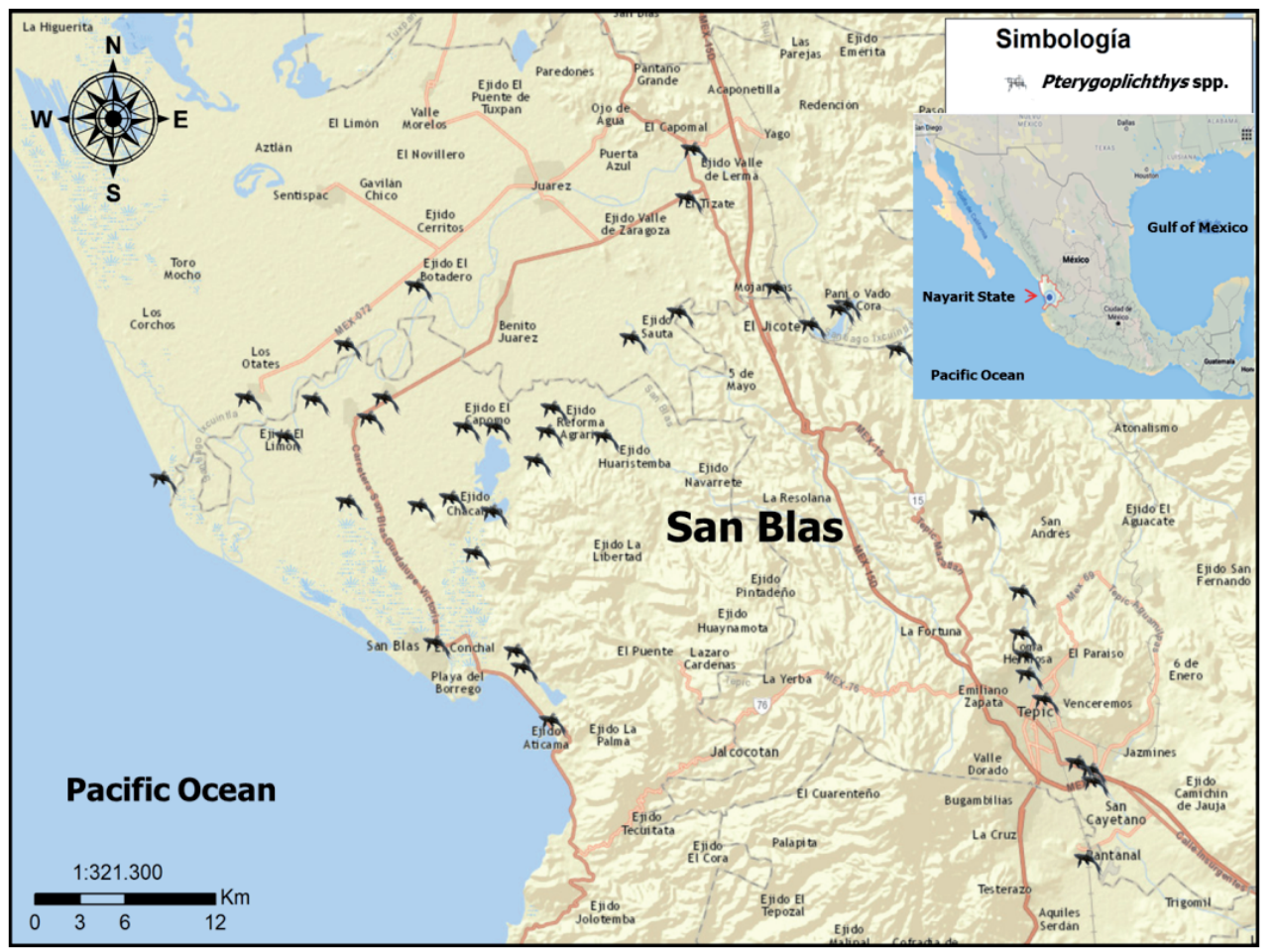

Figure 1. Map of the study area in San Blas, Nayarit, Mexico, shows the lower basin of the Río Grande de Santiago. Fish figures indicate the sites where Amazon sailfin catfish of genus Pterygoplichthys were captured. Mapa de la zona de estudio en San Blas, Nayarit, México, se muestra la cuenca baja del Río Grande de Santiago. Las figuras de los peces indican los sitios donde fueron capturados individuos de Amazon sailfin catfish del género Pterygoplichthys. 
tions of this genus have proliferated in natural areas of Mexico, which has caused a sudden increase in the abundance of juveniles within new environments (Wakida-Kusunoki et al., 2007; Mendoza et al., 2009). In 1995, the first report of a wild population of Loricariid catfish genus Pterygoplichthys was recorded in the Mezcala River, Guerrero (Guzmán \& Barragán, 1997). Three years later, some samples were reportedly found at the Adolfo López Mateos dam "El Infernillo" in the state of Michoacán (Ayala-Pérez et al., 2014). Since then, reports have emerged for the states of Morelos (Mendoza et al., 2009), Campeche (Wakida-Kusunoki \& Amador-del-Angel, 2011), Chiapas (Capps \& Flecker, 2013), Tabasco (Barba et al., 2014; Ríos-Muñoz, 2015) and Sinaloa (Amezcua-Martínez, 2014). Against this backdrop, the aim of the present study is to present the first record and establishment of the genus Pterygoplichthys spp., in freshwater and brackish water of the Coastal Plain of San Blas Nayarit, southeast Gulf of California, Mexico.

\section{MATERIALS AND METHODS}

The armored catfish were collected from the lower basin of the Grande de Santiago River (mainstream and adjacent channels) as well as in the lagoon-estuarine system and wetlands of San Blas (Fig. 1), Nayarit (76054' - 76058' E and 8044' $8049^{\prime} \mathrm{N}$ ), using cast net ( $3 \mathrm{~m}$ high, $1.27 \mathrm{~cm}$ mesh size and $3 \mathrm{~m}$ wide), during various time periods (night and day) in May 2013, March 2014, February 2015, and October 2016. During the study period (2013 to 2016), a total of 400 organisms were collected, which included 220 females and 180 males; 60 fish were fixed with $10 \%$ formaldehyde, whereas the rest were released into water body where they were captured. Pro2030 Dissolved Oxygen, Conductivity, Salinity (YSI Instrument) and $\mathrm{pH}$ (Groline, Model: HI 98118) were used for the water quality variables.

Fish were weighed to the nearest $\pm 0.1 \mathrm{~g}$ with a digital scale. In addition, morphometric measurements, such as total length (TL), standard length (SL), body height (BH) and head height $(\mathrm{HH})$, were taken on their left side to the nearest $0.1 \mathrm{~mm}$, with digital calipers. The length-weight

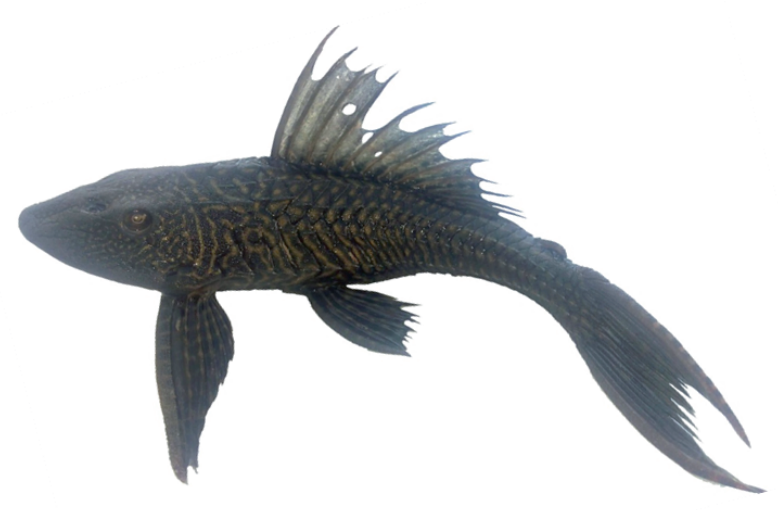

Figure 2. Left side view of Pterygoplichthys captured in the study area. Vista lateral izquierda de Pterygoplichthys capturado en el área de estudio.

ratio (LWR) was determined using the following equation: $W=a L b$ were $\mathrm{W}$ denotes the total weight $(\mathrm{g}), \mathrm{L}$ represents the total length $(\mathrm{cm})$ (Froese et al., 2011; Le Cren, 1951) “ $a$ ” signifies the intersection, and " $b$ " is the regression slope, which, in turn represents the type of growth. If $b=3$, growth is considered isometric. In contrast, the growth is considered allometric when $b \neq 3$ (Ricker 1975). This can be negative $(b<3)$ when fish grow more in length, or positive $(b>3)$ when fish grow more in weight (Froese, 2006). In order to estimate parameter " $a$ " and " $b$ ", a timeline of the potential model on aggregate error was considered $\left(\log _{e}(w i)=\log _{e}(a)+b \log _{e}(L i)+e i\right)$ with a view to stabilizing the variables and obtaining a better fit of the model (Ogle, 2013), t-Student test $(95 \% \mathrm{CI})$ was used to infer the type of growth by parameter b (Sokal \& Rohlf, 1995). Analyses were then performed using the $\mathrm{R}$ programming language with the statistical routines expounded by Ogle (2013). The condition factor $(\mathrm{CF})$ for the species that presented allometric growth was calculated.

$$
C F=\frac{W}{a L^{b}}
$$

(Le Cren, 1951; Froese, 2006) which was estimated using an excel spreadsheet.

Depending on the size of the organisms, the gender was determined by the morphotype char- 
acters and direct observation of the gonads. The fish caught were identified using the keys of Armbruster $(2001,2004)$ and Page and Robins (2006). In addition, digital camera was used to make a photographic catalog; the images show color variations in the ventral marks. Some reference individuals were also included in the ichthyology collection at the National School of Fishing Engineering Academic Unit (ENIP-CI) in San Blas, Nayarit, Mexico.

In addition to using analysis of variance (ANOVA) to determine the differences in morphometric characteristics and body weight of the entire population of Pterygoplichthys, the Tukey test was used to determine the mean difference (Zar, 1996). In particular, the ANCOVA analysis was used to determine the differences in slopes of the female and male captured (Zar, 1996).

\section{RESULTS}

The morphometric characteristics and abdominal patterns (based on coalescence and the arrangement of limited spots) of collected organisms reveal the presence of specimens of genus Ptery- goplichthys in the study area (Fig. 2). The organisms collected presented a wide variation, reflecting in the presence of Pterygoplichthys pardalis (Castelnau, 1855), P. disjunctivus (Weber, 1991) as well as the inter-grade morphological forms or hybrid ( $P$. pardalis x $P$. disjunctivus) (Fig. 3). $P$. pardalis presented discrete black spots on the ventral side of the body (Fig. 3b). Thereafter, the hybrids were joined together, which resulted in the formation of vermiculation (Fig. $3 \mathrm{a}, \mathrm{c}-\mathrm{j}$ ).

A total of 400 fishes were caught from rivers, streams, and canals from May 2013 to October 2016. The weight range of these fishes captured was 22 to $324 \mathrm{~g}$ (Table 1). The specimens of Pterygoplichthys were captured along the Mololoa River micro-basin, on the left bank of the lower Santiago river basin, in front of Matanchen Bay and in front of the sea beach at the mouth of the Santiago River (Fig. 1). During the study period, the range of water quality variables were temperature $\left(18-29^{\circ} \mathrm{C}\right)$, salinity $(0-10 \mathrm{~g} / \mathrm{L}), \mathrm{pH}(7.6-8.0)$, and dissolved oxygen (4.4-6.3 $\mathrm{mg} / \mathrm{L})$. The coexistence of the two morphological forms was found in the majority of localities sampled. This work indicates that the dispersion of the genus continues through the Santiago River basin.

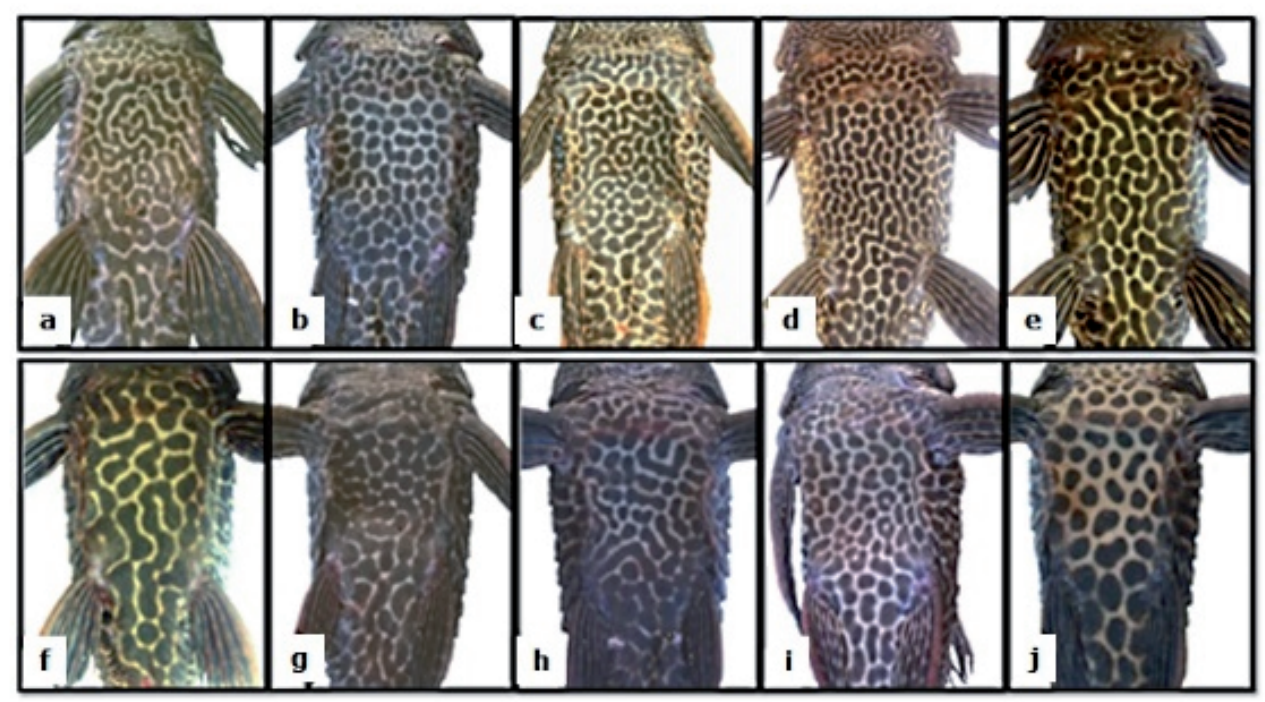

Figure 3. Intermediate ventral view of abdominal patterns of adults of $P$. pardalis and $P$. disjunctivus $\mathrm{x} P$. pardalis. Abdominal view of hybrids (a,c-j), P. pardalis presented discrete black spots on the ventral side of the body (b). Vista ventral intermedia de patrones abdominales de adultos de P. pardalis and P. disjunctivus $x$ P. pardalis. Vista abdominal de híbridos (a, c-j), P. pardalis presentaron puntos negros discretos en el lado ventral del cuerpo (b). 
Table 1. Morphometric characteristics $(\mathrm{cm})$ and body weight $(\mathrm{g})$ of Pterygoplichthys. Mean $( \pm \mathrm{SD})$. Características morfométricas (cm) y peso del cuerpo $(\mathrm{g})$ de Pterygoplichthys. Media $( \pm D S)$.

\begin{tabular}{|c|c|c|c|c|c|c|c|c|c|c|c|c|}
\hline \multirow[t]{2}{*}{ Characteristics } & \multicolumn{2}{|c|}{2013} & \multicolumn{4}{|c|}{2014} & \multicolumn{2}{|c|}{2015} & \multicolumn{4}{|c|}{2016} \\
\hline & Range & Mean & Total & Range & Mean & Total & Range & Mean & Total & Range & Mean & Total \\
\hline Number of Organisms & & & 22 & & & 48 & & & 155 & & 175 & 400 \\
\hline Total length (TL) & $17.0-28.0$ & $22.5 \pm 3.9^{\mathrm{b}}$ & & $23.5-28.0$ & $26.0 \pm 1.4^{\mathrm{a}}$ & & $14.0-33.0$ & $26.7 \pm 3.1^{\mathrm{a}}$ & & $18.0-32.1$ & $27.1 \pm 2.7^{\mathrm{a}}$ & \\
\hline Standard length (SL) & $17.0-21.0$ & $18.9 \pm 1.9^{\mathrm{a}}$ & & $18.0-21.0$ & $19.38 \pm 0.9^{\mathrm{a}}$ & & $10.0-30.0$ & $18.48 \pm 4.1^{\mathrm{a}}$ & & $13.5-26.0$ & $19.2 \pm 2.9^{\mathrm{a}}$ & \\
\hline Abdominal length (AL) & $4.0-7.0$ & $5.7 \pm 1.2^{\mathrm{b}}$ & & $5.0-7.0$ & $5.8 \pm 0.9^{\mathrm{b}}$ & & $1.5-6.5$ & $4.76 \pm 0.7^{b}$ & & $1.5-9.0$ & $7.35 \pm 0.5^{\mathrm{a}}$ & \\
\hline Head length (HL) & $3.5-6.5$ & $5.0 \pm 1.1^{\mathrm{a}}$ & & $4.0-7.0$ & $5.2 \pm 1.2^{\mathrm{a}}$ & & $1.0-5.0$ & $3.99 \pm 0.5^{b}$ & & $6.0-8.0$ & $6.6 \pm 0.6^{\mathrm{a}}$ & \\
\hline Weight (W) & $26.9-180$ & $92.7 \pm 51.9^{\mathrm{b}}$ & & $114-180$ & $140.3 \pm 16.9^{\mathrm{a}}$ & & $22-210$ & $138.3 \pm 35.5^{\mathrm{a}}$ & & $50-324$ & $148.1 \pm 42.8^{\mathrm{a}}$ & \\
\hline Condition Factor (CF) & $1.78-2.07$ & $1.94^{\mathrm{a}}$ & & $1.77-2.01$ & $1.82^{\mathrm{a}}$ & & $1.94-2.28$ & $2.19^{\mathrm{a}}$ & & $1.89-2.15$ & $2.09^{\mathrm{a}}$ & \\
\hline
\end{tabular}

The $\mathrm{L} v s$. W relation of the entire population of organisms collected shows a potential model with an allometric coefficient of $2.6798\left(\mathrm{r}^{2}=0.9044\right.$, $p<0.05$ ) (Fig. 4). After analyzing the LWR of the organisms captured in 2013, a value of $b \geq 3$ $\left(\mathrm{r}^{2}=0.933, \mathrm{~b}=3.061\right)$ was recorded, indicating a positive allometric growth $(p<0.05)$. Meanwhile, a value of $b \leq 3\left(r^{2}=0.88,0.87,0.83 ; b=2.09\right.$, 2.39 and 2.60 , respectively) was recorded with regard to the analysis of the organisms captured from 2014, 2015, which indicated a negative allometric growth $(p<0.05)$. The mean size of females and males was $26.09 \pm 1.74 \mathrm{~cm}, 27.08 \pm$ $1.65 \mathrm{~cm}$ and $136.25 \pm 21.88 \mathrm{~g}, 139.43 \pm 18.48 \mathrm{~g}$, respectively. According to ANCOVA $(p<0.05)$, no significant differences were found between the allometric growth of males $\mathrm{W}=0.01847(\mathrm{~L})^{2.21}$ and females $\mathrm{W}=0.2254(\mathrm{~L})^{2.19}$.

\section{DISCUSSION}

In general, the captured specimens experienced slight variations in the range given by Weber (1992). Initially, the identification of organisms of $P$. pardalis and P. disjunctivus within the genus Pterygoplichthys was rendered complicated due to the involvement of four closely related species such as $P$. anisitsi, $P$. multiradiatus, $P$. pardalis and $P$. disjunctivus that have been separated on the basis of their abdominal patterns and morphology (Nico \& Martin, 2001; Nico et al., 2012), and mtDNA sequences (Wu et al., 2011). However, there has been lack of clarity in establishing the identity of the invaded species in other regions (Bijukumar et al., 2015). Therefore, it can be surmised that the organisms introduced in other regions as well as Mexico can be classified as hybrids $P$. disjunctivus $\mathrm{x} P$. pardalis (Wu et al., 2011).

The size range of captured Pterygoplichthys

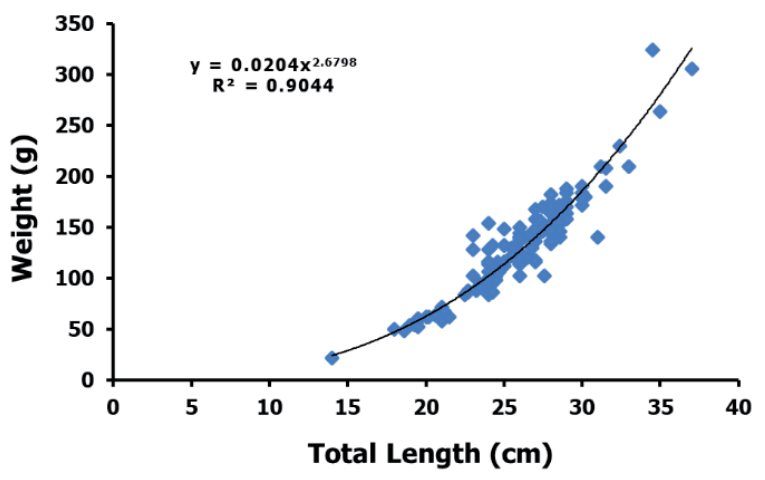

Figure 4. Total length-body weight linear regression of all population of the genus Pterygoplichthys from the Coastal Plain of San Blas, Nayarit, Mexico. Regresión lineal de la longitud total y el peso corporal de todas las poblaciones del género Pterygoplichthys de la llanura costera de San Blas, Nayarit, México. 
was 10 to $30 \mathrm{~cm} \mathrm{SL}$, with a mean of $18.48 \mathrm{~cm}$. These fish could live up to 5.25 years and grow up to $51.5 \mathrm{~cm}$ of SL, with a rapid growth rate of approximately $10 \mathrm{~cm}$ per year (Gibbs et al., 2008). The length-weight recorded a negative allometric growth of Pterygoplichthys, which was consistent with the reports of Rueda-Jasso et al. (2013), Wei et al. (2017) and Hussan et al. (2019). This indicates that fish tend to lose weight and be fewer with greater length. The value of $\mathrm{CF} \geq 1$ is indicative of the fact that the population is healthy and that the translocation of Pterygoplichthys has been favored by what has allowed it to successfully colonize its new environment in the coastal plain of San Blas, Nayarit, southeast of the Gulf of California, Mexico (Le Cren, 1951).

The majority of organisms captured exhibited a variation of intermediate coloration, thus indicating hybridization (Hoover et al., 2014; Bijukumar et al., 2015). This may indicate that the initial invasion has had a long time. In addition, the collections of recent years have shown that many of these organisms have had intermediate morphologies (Fig. 3), reinforcing the theory of the existence of early hybridization event ( $\mathrm{Wu}$ et al., 2011; Godwin et al., 2016). Those hybrid organisms have also been known to increase their adaptation to the study area's environment for better invasion (Seehausen et al., 2008; Karthick et al., 2017). The adaptation of this group to salinities of $10 \mathrm{~g} / \mathrm{L}$ has been demonstrated by capturing organisms in the canals and estuaries of the Municipality of San Blas every year. This, in turn, has been congruent with the maximum tolerance levels that have been recorded for the species of $12 \mathrm{~g} / \mathrm{L}$ (Brion et al., 2013; Kumar et al., 2018) with $100 \%$ survival. The presence of the genus study area could be attributed to the accidental escape of an ornamental fish farm located in the valley of Matatipac, Armadillo locality after Hurricane Kenna in 2002 and organisms from the Grande de Santiago river which spread across to lower parts of the basin, as well as to varying mechanisms distributed in the lentic and lotic systems of freshwater and brackish (up to $10 \mathrm{~g} / \mathrm{L}$ salinity) water coastal plain of the municipality of San Blas, Nayarit, Mexico.

The dispersion of the non-native Loricariid catfish in the Coastal Plain of San Blas, Nayarit, has been facilitated by the "El Jileño" bypass on the Santiago river supplying the irrigation canals to the left and right bank of the Santiago river along with the prevailing interconnectivity hydrological in the area, primarily during the rainy seasons, thus demonstrating its adaptation different habitats of freshwater and brackish water (Capps et al., 2011; Capps \& Flecker, 2013 Jones et al., 2013).

Since the emergence of non-native Loricariid catfish in the area, catches of native species have declined significantly. Contrastingly, there has been an increase in the frequency and volume of the fish catch of the genus Pterygoplichthys. This has already been reported for several Mexican Pacific states such as Guerrero, Michoacán, and Sinaloa with regard to the decline in tilapia catches (Mendoza et al., 2009; Amezcua-Martinez, 2014).

The ecological effects of Pterygoplichthy in the study area have not been determined in particular. However, an increase in populations of non-native Loricariid catfish has been observed over time along with a decrease in local fisheries primarily from Macrobrachium spp. such as what has been reported in the Southeast of Mexico (Wakida-Kusunoki et al., 2008). The results obtained in this study suggest that the genus Pterygoplichthys can be totally considered an invasive taxon, category E (Jones et al., 2011), with individuals dispersing, surviving, and reproducing in multiple sites across a greater or lesser spectrum of habitats and extent of occurrence. As reported, the effect of Loricariid catfish on the environment include the following: drastic modification of nutrient regimes and biogeochemical cycling, siltation, and erosion caused by burrowing males, with the effect on biota as a vector for nonnative parasites acting as egg predators of native fishes and resulting in declining fish food resources (Orfinger \& Goodding, 2018).

Juvenile stages of Pterygoplichthys have assumed significance for the settlement and recruitment in the study area (Sheaves et al., 2006), due to the type of habitat that comprises of a network of drainage channels and lagoons with adequate conditions for feeding and reproduction of Pterygoplichthys in such a manner that the settlement and recruitment have been related in the same habitat where adults are found, as report- 
ed for other fish (Garcia-Rubies \& Macpherson, 1995). However, more detailed studies were required in the lower basin of the Grande de Santiago River and San Blas River in order to determine the temporal and spatial variation in settlement and recruitment of Pterygoplichthys in the study area's canal and lagoon system.

This work shows that the dispersion of Loricariidae catfish genus Pterygoplichthys continues in the Mexican Pacific coast, and as reported by Wakida-Kusunoki and Amador-Del Angel (2008), in the coastal area of the Gulf of Mexico. Therefore, control and eradication is urgently necessitated. Finally, the species of the genus Pterygoplichthy have not been considered in the management plans of the Protected Natural Area adjacent to the study area called "Marismas Nacionales-Nayarit" since the studied species will significantly endanger the native biodiversity of the Biosphere Reserve. In general, the presence of juveniles, adults, and mature females in several areas of the coastal plain of San Blas Nayarit indicates that the species is already well-established in the region. This, in turn, is endangering local species and the equilibrium of the ecosystem.

\section{REFERENCES}

AMEZCUA-MARTÍNEZ, F. 2014. Colonization in the lagoon of Chiricahueto (Sinaloa, México) by the invasive species Pterygoplichthys spp: study cases in Mexican ecosystems. Invasive Aquatic Species: Study cases in Mexican Ecosystems, SEMARNAT, INECC, UPEI, Ciudad de México, México; pp. 273-291.

ARMBRUSTER, J. W. 2001. Loricariid Home Page. http://www.auburn.edu/academic/ science_math/res_area/loricariid/fish_key/ lorhome/main.html. On-line version dated February 2, 2010.

ARMBRUSTER, J. W. 2004. Phylogenetic relationships of the sucker mouth armoured catfishes (Loricariidae) with emphasis on the Hypostominae and the Ancistrinae. Zoological Journal of the Linnaean Society, 141: 1-80. DOI: 10.1111/j.1096-3642.2004.00109.x

AYALA-PÉREZ, L. A., A. D. PINEDA-PERAL-
TA, H. ÁLVAREZ-GUILLÉN \& L. E. AMADOR-DEL ÁNGEL. 2014. El pez diablo (Pterygoplichthys spp.) en las cabeceras estuarinas de la Laguna de Términos, Campeche. In: Low-Pfeng AM, Quijón PA, Peters-Recagno EM (eds), Especies invasoras acuáticas: casos de estudio en ecosistemas de México. SEMARNAT, INECC, UPEI, Ciudad de México, México, pp 313-336

BARBA, E., J. JUÁREZ-FLORES \& M. MAGAÑA-VÁZQUEZ. 2014. Nuevos registros de plecos (Pterygoplichthys pardalis) (Siluriformes: Loricariidae) en las cuencas del rio Grijalva y Tonalá, Pajonal-Machona, Tabasco. En: Low A. M., P. A. Quijon y E. M. Peters (Eds.): Especies invasoras acuáticas: casos de estudio en ecosistemas de México. pp. 233-251. Secretaria de Medio Ambiente y Recursos Naturales (Semarnat), Instituto Nacional de Ecología y Cambio Climático (INECC), University of Prince Edward Island (UPEI).

BIJUKUMAR, A., R. SMRITHY, U. SURESHKUMAR \& S. GEORGE. 2015. Invasion of South American suckermouth armoured catfishes Pterygoplichthys spp. (Loricariidae) in Kerala, India- a case study. Journal of Threatened Taxa, 7(3): 6987-6995. DOI: 10.11609/JoTT.04133.6987-95

BRION, M. A., J. G. G. J. C. UY, J. CHAVEZ \& J. S. CARANDANG IV. 2013. Salinity tolerance of introduced South American sailfin catfishes (Loricariidae: Pterygoplichthys Gill, 1858). Philippine Journal of Science, 142: 13-19.

CAPPS, K. A., L. G. NICO, M. MENDOZACARRANZA, W. ARÉVALO-FRÍAS, A. J. ROPECKI, S. A. HEILPRIN \& R. RODILES-HERNÁNDEZ. 2011. Salinity tolerance of non-native suckermouth armoured catfish (Loricariidae: Pterygoplichthys) in south-eastern Mexico: implications for invasion and dispersal. Aquatic Conservation: Marine and Freshwater Ecosystems, 21: 528-540. DOI: $10.1002 /$ aqc. 1210

CAPPS, K. A. \& A. S. FLECKER. 2013. Invasive aquarium fish transform ecosystem nutrient dynamics. Proceedings of the Royal Society of London B: Biological Sciences, 280: 
1520. DOI: $10.1098 / \mathrm{rspb} .2013 .1520$

CHAICHANA, R. \& S. JONGPHADUNGKIET. 2012. Assessment of the invasive catfish Pterygoplichthys pardalis (Castelnau, 1855) in Thailand: ecological impacts and biological control alternatives. Tropical Zoology, 25(4): 173-182. DOI: 10.1080/14634988.2017.1407204

FROESE, R. 2006. Cube law, condition factor and weight-length relationships: history, meta analysis and recommendations. Journal of applied ichthyology, 22: 241-253. DOI: 10.1111/j.1439-0426.200

FROESE, R., A. C. TSIKLIRAS \& K. I. STERGIOU. 2011. Editorial note on weight-length relations of fishes. Acta Ichthyologica et Piscatoria, 41: 261-263. DOI:10.3750/AIP2011. 41.4.01

GARCIA-RUBIES A \& E. MACPHERSON. 1995. Substrate use and temporal pattern of recruitment in juvenile fishes of the Mediterranean littoral. Marine Biology, 124: 35-42. DOI: $10.1007 / \mathrm{BF} 00349144$

GIBBS, M. A., J. H. SHIELDS, D. W. LOCK, K. M. TALMADGE \& T. M. FARREL. 2008. Reproduction in an invasive exotic catfish Pterygoplichthys disjunctivus in Volusia Blue Spring, Florida, USA. Journal of Fish Biology, 73: 1562-1572. DOI: 10.1111/j.1095-8649. 2008.02031.x

GODWIN, J. C., D. C. WERNEKE, D. A. STEEN \& J. W. ARMBRUSTER. 2016. Two significant records of exotic neotropical freshwater fish observed in southern Alabama. Southeastern Naturalist, 15: N57-N60. DOI: 10.1656/058.015.0401

GUZMÁN, A. F. \& J. BARRAGÁN. 1997. Presencia de bagre sudamericano (Osteichthyes: Loricariidae) en el río Mezcala, Guerrero, México. Vertebrata Mexicana, 3: 1-4.

HOOVER, J. J., C. E. MURPHY \& J. KILLGORE. 2014. Ecological impacts of suckermouth catfishes (Loricariidae) in North America: A conceptual model. Aquatic Nuisance Species Research Program, 14(1): 1-20.

HUSSAN, A., J. K. SUNDARAY, R. N. MANDAL, F. HOQUE, A. DAS, P. P. CHAKRABARTI \& S. ADHIKARI. 2019. Invasion of non-indigenous suckermouth armoured catfish of the genus Pterygoplich- thys (Loricariidae) in the East Kolkata Wetlands: stakeholders' perception. Indian Journal of Fisheries, 66(2): 29-42. DOI: 10.21077/ijf.2019.66.2.86267-05

JONES, R. W., O. L. F. WEYL, E. R. SWARTZ \& M. P. HILL. 2013. Using a unified invasion framework to characterize Africa's first Loricariid catfish invasion. Biological Invasions, 15: 2139-2145. DOI: 10.1007/s10530013-0438-7

JUMAWAN, J. C., B. M. VALLEJO, A. A. HERRERA, C. C. BUERANO \& I. K. FONTANILLA. 2011. DNA barcodes of the suckermouth sailfin catfish Pterygoplichthys (Siluriformes: Loricariidae) in the Marikina River system, Philippines: Molecular perspective of an invasive alien fish species. Journal of Materials Science Letters, 4(2): 103-113

KARTHICK, S., S. AANAND \& P. JAWAHAR. 2017. Record of non-native loricariid catfish, Pterygoplichthys disjunctivus (Weber, 1991) (Siluriformes, Loricariidae) in Kadamba Tank - Tamiraparani River Basin, Tamilnadu. Journal of Experimental Zoology India, 20(2): 677-681.

KUMAR, A.B., P. J. SCHOFIELD, S. RAJ \& S. SATHEESH. 2018. Salinity tolerance of non-native suckermouth armoured catfish (Loricariidae: Pterygoplichthys spp.) from Kerala, India. Management of Biological Invasions, 9(1): 49-57. DOI: 10.3391/mbi. 2018.9.1.05

LE CREN, E. D. 1951. The length-weight relationship and seasonal cycle in gonad weight and condition in the perch (Perca fluviatilis). The Journal of Animal Ecology, 20: 201-219.

MENDOZA, A. R., G. C. ESCALERA, S. CONTRERAS-BALDERAS, O. P. KOLEFF, M. C. RAMIREZ, T. P. ALVAREZ, D. M. ARROYO \& M. A. ORBE. 2009. Invasion of armored catfish in Infiernillo reservoir, Michoacán-Guerrero, México, socio-economic impact analysis: a tale of two invaders. In: Trinational risk assessment guidelines for aquatic alien invasive species. Test cases for the Snakeheads (Channidae) and Armored Catfishes (Loricariidae) in North American Inland Waters Commission for Environmen- 
tal Cooperation, pp 51-59.

MURALIDHARAN, M., K. MANIKANDAN \& M. GOBI. 2015. Extended distribution of the invasive sucker catfish Pterygoplichthys pardalis (Pisces: Loricariidae) to Cauvery river system of Peninsular India. International Journal of Aquatic Biology, 3(1): 14-18. DOI: 10.22034/ijab.v3i1.41

NICO, L. G. \& T. R. MARTIN. 2001. The South American Suckermouth Armored Catfish, Pterygoplichthys anisitsi (Pisces: Loricariidae), in Texas, with comments on foreign fish introductions in the American Southwest. Southwestern Naturalist, 46(1): 98-104. DOI: 10.2307/3672381

NICO, L. G., P. L. BUTT, G. R. JOHNSTON, H. L. JELKS, M. KAIL \& S. WALSH. 2012. Discovery of South American suckermouth armored catfishes (Loricariidae, Pterygoplichthys spp.) in the Santa Fe River drainage, Suwannee River basin, USA. BioInvasions Records, 1: 179-200. DOI: 10.3391/bir.2012. 1.3.04

OGLE, D. 2013. fishR Vignette - Fish Condition and Relative Weights. Retrieved from Ashland, Wisconsin: https://fishr.files.wordpress.com/ 2013/04/relativeweight.pdf

ORFINGER, A. B. \& D. D. GOODDING. 2018. The global invasion of the suckermouth armored catfish genus Pterygoplichthys (Siluriformes: Loricariidae): annotated list of species, distributional summary, and assessment of impacts. Zoological Studies, 57: 1-7. DOI: 10.6620/ZS.2018.57-07

PAGE, L. M. \& R. ROBINS. 2006. Identification of sailfin catfishes (Teleostei: Locariidae) in Southeastern Asia. The Raffles Bulletin of Zoology, 54(2): 455-457.

RICKER, W. J. 1975. Computation and interpretation of biological statistics of fish populations. Ottawa, Ontario. Fisheries Research Board of Canada Bulletin 191, 382.

RÍOS-MUÑOZ, C. 2015. Depredación de pez diablo (Loricariidae: Pterygoplichthys) por el cormorán oliváceo (Phalacrocorax brasilianus) en Villahermosa, Tabasco, México. Huitzil, Revista Mexicana de Ornitología, 16(2): 62-65.

RUEDA-JASSO, R. A., A. CAMPOS-MENDO-
ZA, F. ARREGUIN-SANCHEZ, E. DIAZPARDO \& C. A. MARTINEZ-PALACIOS. 2013. The biological and reproductive parameters of the invasive armored catfish Pterygoplichthys disjunctivus from Adolfo Lopez Mateos El Infiernillo Reservoir, MichoacanGuerrero, Mexico. Revista Mexicana de Biodiversidad, 84: 318-326. DOI: 10.7550/ rmb26091

SEEHAUSEN, O., G. TAKIMOTO, D. ROY \& J. JOKELA. 2008. Speciation reversal and biodiversity dynamics with hybridization in changing environments. Molecular Ecology, 17(1): 30-44. DOI: 10.1111/j.1365-294X.2007. 03529.x

SHEAVES M, R, BAKER \& R. JOHNSTON. 2006. Marine nurseries and effective juvenile habitats: An alternative view. Marine Ecology Progress Series, 318:303-306. DOI: 10.3354/ meps 318303

SIMONOVIĆ, P, V. NIKOLIĆ \& S. GRUJIĆ. 2010. Amazon sailfin catfish Pterygoplichthys pardalis (Castellnnau, 1855) (Loricariidae, Siluriformes), a new fish species recorded in the Serbian section of the Danube River. Second Balkan Conference on Biology, 21-23 May 2010, Plovdiv, Biotechnol. \& Biotechnol. Eq. 24/2010/ Sespecial Edition/On-Line, 655-660pp. DOI: 10.1080/ 13102818.2010 .10817916

SOKAL, R. R. \& F. J. ROHLF. 1995. Biometry: the principles and practices of statistics in biological research. 3rd ed. Freeman, New York.

WAKIDA-KUSUNOKI, A. T., R. RUIZ-CARUS \& E. AMADOR-DEL-ANGEL. 2007. Amazon sailfin catfish, Pterygoplichthys pardalis (Castelnau, 1855) (Loricariidae), another exotic species established in southeastern Mexico. The Southwestern Naturalist, 52(1): 141-144. https://www.jstor.org/stable/ 20424800

WAKIDA-KUSUNOKI, A. T. \& E. AMADORDEL-ANGEL. 2008. New records of the sailfish catfishes Pterygoplichthys pardalis (Castelnau 1855) and P. disjunctivus (Weber 1991) (Siluriformes: Loricariidae) in Southeastern Mexico. Hidrobiológica, 18(3): 251-256 
WAKIDA-KUSUNOKI, A. T. \& E. AMADORDEL ÁNGEL. 2011. Aspectos biológicos del pleco invasor Pterygoplichthys pardalis (Teleostei: Loricariidae) en el río Palizada, Campeche, México. Revista Mexicana de Biodiversidad, 82(3): 870-878. DOI: 10.22201/ ib.20078706e.2011.3.739

WAKIDA-KUSUNOKI, A. T., E. AMADORDEL-ANGEL, E. ROMERO-HERNANDEZ \& L. M. BOZADA. 2016. Range expansion of the invasive Amazon Sailfin Catfish, Pterygoplichthys pardalis (Castelnau, 1855), in the central and southeastern Gulf of Mexico. Limnetica, 35: 297-302. DOI: 10.23818/limn. 35.24

WEBER, C. 1992. Revision du genre Pterygoplichthys sensu lato (Pisces, Siluriformes, Loricariidae). Revue française d'Aquariologie Herpétologie, 19: 1-36.

WEI, H., G. H. COPP, L. VILIZZI, F. LIU, D. GU, D. LUO \& Y. HU. 2017. The distribution, establishment and life-history traits of non-native sailfin catfishes Pterygoplichthys spp. in the Guangdong Province of China. Aquatic Invasions, 12(2), 241-249. DOI: 10.3391/ai.2017.12.2.11

WU, L. W., C. C. LIU \& S. M. LIN. 2011. Identification of exotic sailfin catfish species (Pterygoplichthys, Loricariidae) in Taiwan based on morphology and mtDNA sequences. Zoological Studies, 50 (2): 235-246.

YU, S. C. S. \& J. P. QUILANG. 2014. Molecular phylogeny of catfishes (Teleostei: Siluriformes) in the Philippines using the mitochondrial genes COI, Cyt b, 16SrRNA, and the Nuclear Genes Rag1 and Rag2. Philippine Journal of Science, 143(2): 187-198.

ZAR, J. H. 1996. Biostatistical analysis. New Jersey: Prentice-Hall International Editions

ZWORYKIN, D. D. \& S. V. BUDAEV. 2013. Non-indigenous armoured catfish in Vietnam: invasion and systematics. Ichthyological Research, 60(4): 327-333. DOI: $10.1007 /$ s10228-013-0356-9 